\title{
Research of Hydrochemical Properties of Hyporheic Zone along the WeiHe River in Shanxi Segment
}

\author{
Nan Zhang1, Hong Jiang ${ }^{2}$, Shu Li ${ }^{1}$, Pan Zhang ${ }^{1}$, Xiaohui Su${ }^{1}$ \\ ${ }^{1}$ Yellow River Institute of Hydraulic Research, Zhengzhou, China \\ ${ }^{2}$ Yellow River Basin Water Resources Protection Bureau, Zhengzhou, China \\ Email: zhangnan19810202@126.com
}

How to cite this paper: Zhang, N., Jiang, H., Li, S., Zhang, P. and Su, X.H. (2017) Research of Hydrochemical Properties of Hyporheic Zone along the WeiHe River in Shanxi Segment. Journal of Geoscience and Environment Protection, 5, 226-232. https://doi.org/10.4236/gep.2017.56020

Received: February 23, 2017 Accepted: September 25, 2017 Published: September 28, 2017

\begin{abstract}
By sampling the undercurrent belts of riverfront, shoal and riverbed at Xianyang, Xi'an, Lintong and Huaxian in Weihe basin of Shaanxi province in the summer and winter of 2014 and analyzed the water chemical character through Piper trilinear chart, This thesis has come to the following conclusions: (1) PH in shoal range from 7.42 to 7.98 , and in riverfront, the average is 7.58 , present alkaline. The TDS in riverfront is higher than that of river water, it range from 506.5 to $824,616.06 \mathrm{mg} \cdot \mathrm{L}^{-1}$ in average. (2) All of the water at riverfront, shoal and riverbed under the influence of carbonate. The concentration of ionic concentration at shoal is between riverbed and riverfront, by contrast, it close to riverfront. This result means the shoal recharged by both surface and river water, and the groundwater recharge is more conspicuous than surface water. Besides, from upstream to downstream, the two kinds of main ions $\left(\mathrm{HCO}_{3}^{-}\right.$and $\left.\mathrm{Ca}^{2+}\right)$ have little change in the same river, it related to such factors as river evaporation, the exchange interaction of surface and underground water and so on.
\end{abstract}

\section{Keywords}

Hyporheic Zone, Weihe River, Hydrochemistry, Piper

\section{Introduction}

Surface-subsurface exchange (hyporheic exchange) across the river bed plays an important role in the fate of solutes and contaminants in rivers. With the deepening of river water ecology and environment research, the ecology research of river and groundwater mixing area (hyporheic zone) has become a hot topic. The hyporheic zone is an important component of river or stream continuity, 
effectively connecting the land, surface and subsurface components of the river [1].

For the Weihe River, the water pollution is serious and the water quality is complex [2]. In this paper, the water chemistry of the latent water zone in the Shaanxi section of the Weihe River basin is analyzed by the mathematical statistics and the Piper three-line diagram method. Which is beneficial to the development and utilization of regional shallow groundwater, increase the amount of available water resources, and make the shallow groundwater in a benign circulation, to a certain extent alleviate the contradiction between the economic development and the shortage of water resources in the Weihe River basin.

\section{Materials and Methods}

\subsection{Overview of the Study Area}

Weihe River belongs to the arid and semiarid areas of western China and is the largest tributary of the Yellow River. It is the river of life in the Guanzhong area of Shaanxi Province. It originated from the north of the Bird Mountain in the southwest of Weiyuan County, Gansu Province. It covers three provinces of Gansu, Ningxia and Shaanxi, pour into the Yellow River at the Tongguan County. The total drainage area is $134,000 \mathrm{~km}^{2}$. Shaanxi Weihe River in the Weihe River Basin is mainly the middle and lower reaches of the Weihe river basin area, Baoji gorge to Xianyang as middle reaches, the river is about $180 \mathrm{~km}$ long, the river is wide; Xianyang to Tongguan into the yellow mouth for the downstream, the river is about $208 \mathrm{~km}$, river wide gentle, serious siltation of sediment .

\subsection{Sampling Point Distribution and Research Methods}

Based on the field investigation and data collection and analysis of Weihe River in Shaanxi section of Weihe River, four representative areas (Xianyang, Xi'an, Lintong and Huaxian) in the middle and lower reaches of the Weihe River are selected (Figure 1). In each study area, Set the test points (The test time, the number of distribution points in Table 1). Each test point is divided into three groups of water samples tested, that is, the river bank, beach area, river bed (Figure 2), in order to ensure consistency of water samples, each group were taken 2 to 3 samples, the test results take the mean. Test time for the 2014 summer, winter two seasons.

Sample test items include: $\mathrm{PH}, \mathrm{K}^{+}, \mathrm{Na}^{+}, \mathrm{Ca}^{+}, \mathrm{Mg}^{+}, \mathrm{HCO}_{3}^{-}, \mathrm{Cl}^{-}, \mathrm{SO}_{4}^{2-}$, $\mathrm{NO}_{3}^{-}$and total soluble solid indicators. $\mathrm{PH}$ is detected by PHS-3C

Table 1. Average stream discharge and stream level in four gauges stations.

\begin{tabular}{ccccc}
\hline Station location & $\begin{array}{c}\text { Longitude and } \\
\text { Latitude }\end{array}$ & $\begin{array}{c}\text { Mean stream } \\
\text { discharge }\left(\mathrm{m}^{3} / \mathrm{s}\right)\end{array}$ & $\begin{array}{c}\text { Mean stream level } \\
(\mathrm{m})\end{array}$ & Date range \\
\hline A & $107.05 / 34.38$ & 85 & 493 & $2004-2014$ \\
B & $107.7 / 34.30$ & 158 & 382 & $2004-2014$ \\
C & $108.7 / 34.32$ & 234 & 352 & $2004-2014$ \\
D & $109.77 / 34.58$ & 257 & 336 & $2004-2014$ \\
\hline
\end{tabular}




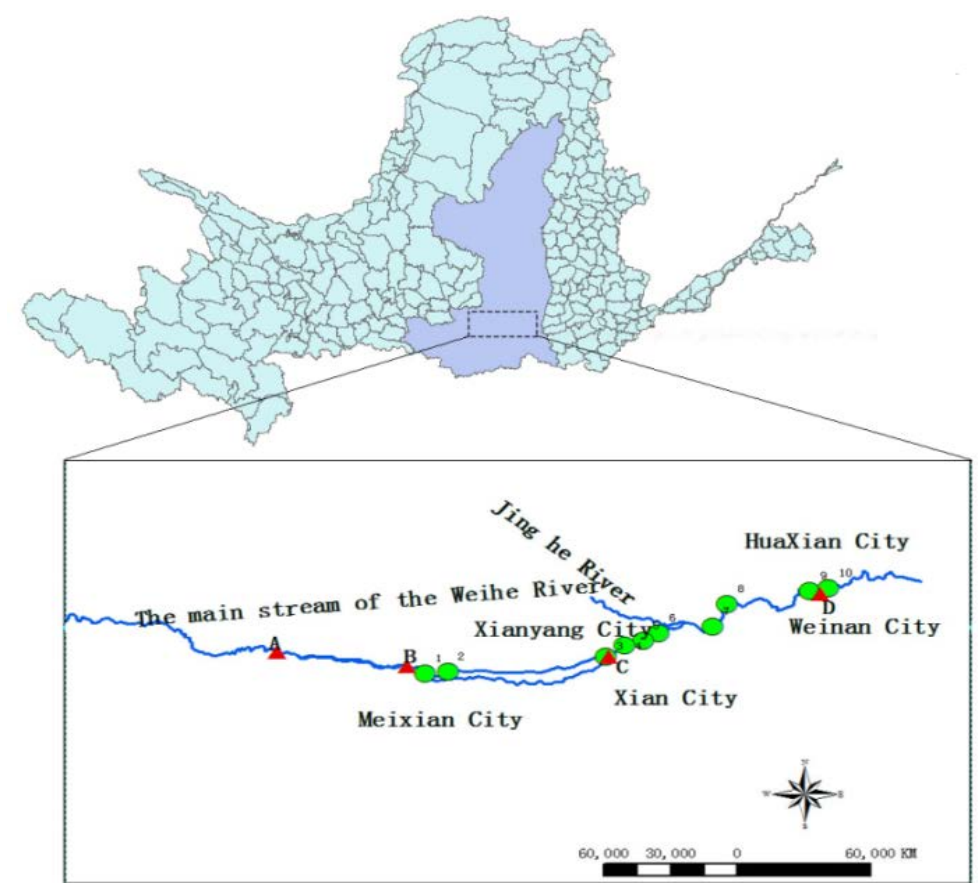

Figure 1. Map of the study area and tests sites (1 to 10) dot represent the test sites, Triangle represent gauges station.

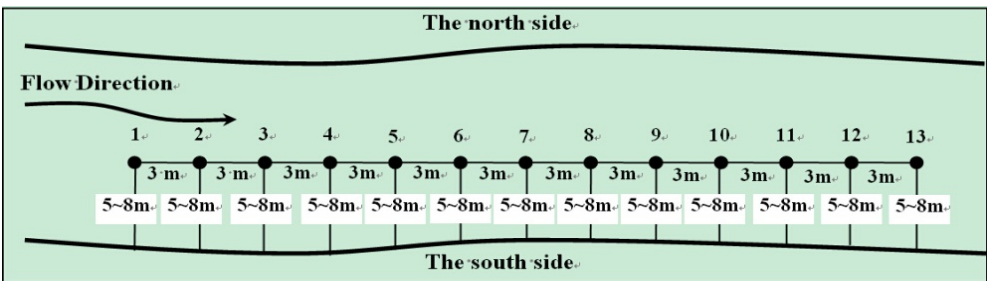

Figure 2. Sketch map of test points.

(Digital ph meter), $\mathrm{K}^{+}, \mathrm{Na}^{+}, \mathrm{Ca}^{+}, \mathrm{Mg}^{+}$are detected by iCAP6300 Radial (Full spectrum direct reading plasma emission spectrometer), $\mathrm{Cl}^{-}, \mathrm{SO}_{4}^{2-}, \mathrm{NO}_{3}^{-}$ are detected by ICS-2000 (ion chromatography).

\section{Hydrochemical Distribution Characteristics in the Study Area}

First of all, the water samples in the study area were sampled scientifically and systematically. Analyze and test relevant water chemistry parameters, and then use of water chemistry software (Aqua Chem 4.0) [3] [4] [5]. The spatial and temporal variability of the chemical components in the riverbank, beach area and riverbed were studied comprehensively by means of statistical analysis and Piper three-line diagram.

\subsection{Tatistical Analysis}

The statistical characteristics of water chemistry and its hydrochemical parameters in the study area, the river flows along the riverbank, the beach area and the riverbed are shown in Table 2. The results showed that the $\mathrm{pH}$ value of the 
Table 2. The test of water chemical type distribution.

\begin{tabular}{ccccc}
\hline Tests & Xianyang & Xian & LinTong & Huaxian \\
\hline River bank & $\mathrm{Ca}-\mathrm{Na}-\mathrm{Mg}-\mathrm{HCO}_{3}-\mathrm{SO}_{4}$ & $\mathrm{Ca}-\mathrm{Na}-\mathrm{Mg}-\mathrm{HCO}_{3}-\mathrm{SO}_{4}-\mathrm{Cl}$ & $\mathrm{Na}-\mathrm{Mg}-\mathrm{Ca} \mathrm{SO}_{4}-\mathrm{Cl}_{-} \mathrm{HCO}_{3}$ & $\mathrm{Ca}-\mathrm{Na}-\mathrm{SO}_{4}-\mathrm{HCO}$ \\
Beach are & $\mathrm{Ca}-\mathrm{Na}-\mathrm{Mg}-\mathrm{HCO}_{3}-\mathrm{SO}_{4}-\mathrm{Cl}$ & $\mathrm{Ca}-\mathrm{Na}-\mathrm{Mg}-\mathrm{HCO}_{3}-\mathrm{SO}_{4}-\mathrm{Cl}$ & $\mathrm{Na}-\mathrm{Ca}-\mathrm{Mg}-\mathrm{HCO}_{3}-\mathrm{SO}_{4}-\mathrm{Cl}$ & $\mathrm{Ca}-\mathrm{Mg}-\mathrm{Na}-\mathrm{HCO}-\mathrm{SO}_{4}$ \\
River bed & $\mathrm{Ca}-\mathrm{Na}-\mathrm{Mg}-\mathrm{HCO}_{3}-\mathrm{SO}_{4}-\mathrm{Cl}$ & $\mathrm{Ca}-\mathrm{Na}-\mathrm{Mg}-\mathrm{HCO}_{3}-\mathrm{SO}_{4}-\mathrm{Cl}$ & $\mathrm{Na}-\mathrm{Ca}-\mathrm{Mg}-\mathrm{HCO}_{3}-\mathrm{SO}_{4}-\mathrm{Cl}$ & $\mathrm{Ca}-\mathrm{Na}-\mathrm{Mg}-\mathrm{HCO}-\mathrm{SO}_{4}-\mathrm{Cl}$ \\
\hline
\end{tabular}

riverbed, beach area and riverbed in Xianyang, Xian, Lintong and Huaxian were all weakly alkaline. The $\mathrm{pH}$ value ranged from 7.32 to 7.99 with an average value of 7.65 .

During the four sampling periods in the summer and winter of 2014, the variation range of TDS in the riverbed of the Weihe River in the Shaanxi section of the Weihe River was $493-794 \mathrm{mg} \cdot \mathrm{L}^{-1}$, with an average value of $586.63 \mathrm{mg} \cdot \mathrm{L}^{-1}$, which is much higher than the average value of TDS $\left(115 \mathrm{mg} \cdot \mathrm{L}^{-1}\right)$ in the world, but its TDS is less than $1 \mathrm{~g} \cdot \mathrm{L}^{-1}$, still belongs to the freshwater river. The minimum value appears in the most upstream Xianyang area. Other point of water samples due to evaporation and other factors, the runoff process in summer and winter increased slightly. The hydrochemical type of river water is mainly $\mathrm{HCO}_{3}^{-}, \mathrm{Ca}^{2+}$, which has obvious characteristics of freshwater river. The hydrochemical types of some sites are $\mathrm{HCO}_{3}^{-}, \mathrm{Ca}^{2+}, \mathrm{Na}^{+}$and $\mathrm{Mg}^{2+}$.

The variation of $\mathrm{PH}$ value in the shoal area was from 7.42 to 7.98 , and the range of TDS varied from 506.5 to 824 with an average of $616.06 \mathrm{mg} \cdot \mathrm{L}^{-1}$, which was higher than that of river water TDS. The $\mathrm{HCO}_{3}^{-}, \mathrm{Ca}^{2+}$ is the main hydrochemical type in the shoal area, the hydrochemical types of some sites are $\mathrm{HCO}_{3}^{-}, \mathrm{Ca}^{2+}, \mathrm{Mg}^{2+}, \mathrm{Na}^{+}$, and $\mathrm{HCO}_{3}^{-}, \mathrm{Na}^{+}, \mathrm{Ca}^{2+}, \mathrm{Mg}^{2+}$.

The average $\mathrm{pH}$ of the river bank was 7.58 , alkaline, the average concentration of anion and anion from low to high for the $\mathrm{K}^{+}<\mathrm{NO}_{3}^{-}<\mathrm{Mg}^{2+}<\mathrm{Cl}^{-}<\mathrm{Na}^{+}<$ $\mathrm{Ca}^{2+}<\mathrm{SO}_{4}^{2-}<\mathrm{HCO}_{3}^{-}$. The average TDS was $565 \mathrm{mg} \cdot \mathrm{L}^{-1}$.

It can be seen that the cationic concentration of Xianyang, Xian, Huaxian in summer and winter in the main part of the Weihe River is from $\mathrm{Ca}^{2+}>\mathrm{Na}^{+}>$ $\mathrm{Mg}^{2+}>\mathrm{K}^{+}$. The order of cationic concentration in the summer and winter of Lintong is $\mathrm{Na}^{+}>\mathrm{Ca}^{2+}>\mathrm{Mg}^{2+}>\mathrm{K}^{+}$. $\mathrm{Na}^{+}$ions become the ions with the highest concentration in the cation. The reason of the change may be that the upper tributaries of the Shaanxi section of the Weihe River, the Jinghe River. On the other hand Xianyang, Shaanxi section of the river near the water source distribution is widespread, high salt content of groundwater recharge river. The order of anion concentration from high to low is: $\mathrm{HCO}_{3}^{-}>\mathrm{SO}_{4}^{2-}>\mathrm{Cl}^{-}>\mathrm{NO}_{3}^{-}$. $\mathrm{HCO}_{3}^{-}$ion is the highest concentration of ions in the anion, $\mathrm{PH}$ value is alkaline, reflecting the river bank, beach area, the river bed are subject to carbonated water.

\subsection{Piper Three-Line Diagram Method}

In order to analyze the chemical composition of the river water in the mainstream of the Weihe River in Shaanxi Province, the main ions of the water sam- 
ples in the river were according to the equivalent concentration of international common water chemical classification method, using AquaChem (4.0) software rendering.

Figures 3(a)-(d) are the three-line diagrams of water samples at Xianyang, Xi'an, Lintong, Huaxian district banks, beach area, river bed. It can be seen from the figure that the distribution of anions and cations in the four sampling areas is located in the middle of the triangle with little change, only the cations of Huaxian district are biased towards the lower right corner, and the anions of Xianyang district tend to the lower left corner. The distribution of hydrochemical types in the four sampling areas is shown in Table 2 . The change of ion position indicates that with the river water flow, water-rock interaction, evaporation concentration and water access to the river around the role, the water content in the water changes, and the water chemistry type also changes. In the case of the cationic triangles, the components are distributed in the middle and the right side of the graph. $\mathrm{Ca}^{2+}$ and $\mathrm{Mg}^{2+}$ are the main components in the cation, these two types of ions are mainly derived from carbonate and alkaline earth metals. From the Piper three-line diagram shows that the sampling point in Xianyang total mg equivalent of the number of cations, $\mathrm{Ca}^{2+}$ accounted for about $70 \%$, $\mathrm{Mg}^{2+}$ accounted for $18 \%$, Na accounted for $12 \%$. From Xianyang to Lintong, the proportion of $\mathrm{Ca}^{2+}$ increased from $70 \%$ to $80 \%$, and the proportion of $\mathrm{Mg}^{2+}$ and

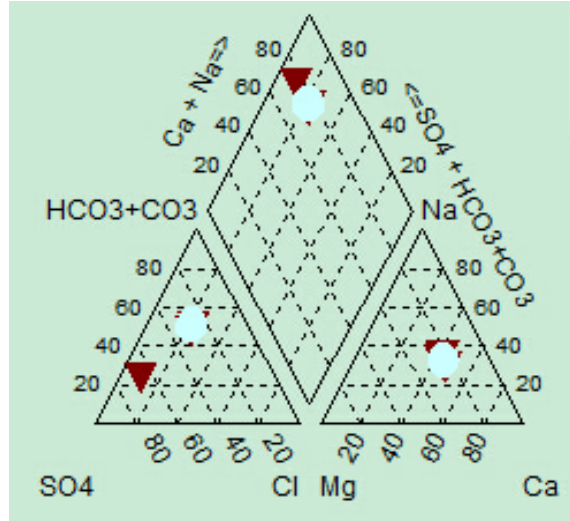

(a)

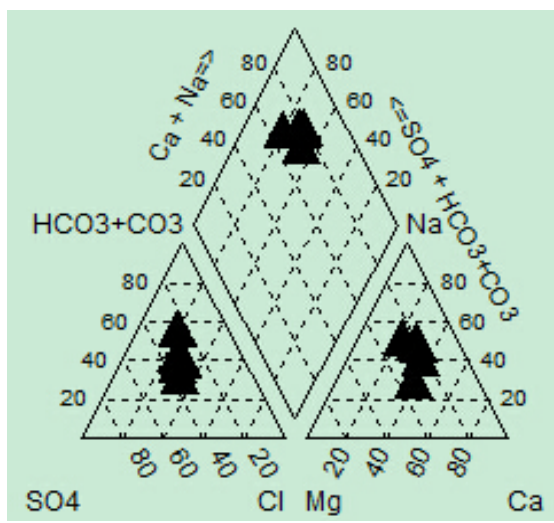

(c)

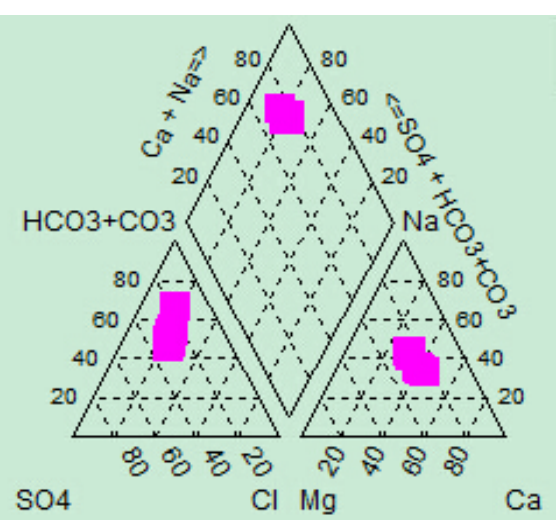

(b)

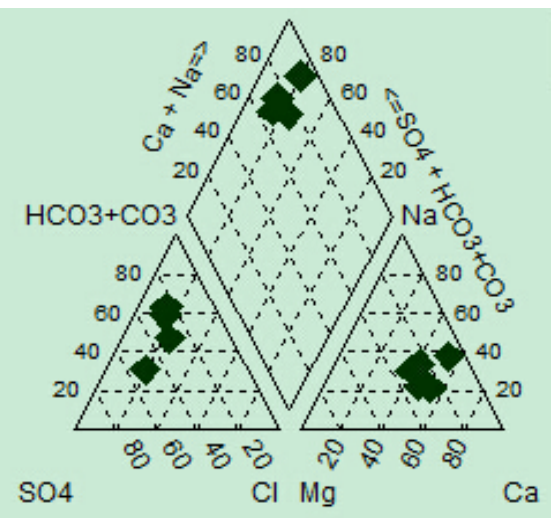

(d)

Figure 3. Piperp in four tests. 
$\mathrm{Na}+$ ions decreased in the total $\mathrm{mg}$ equivalent of cations. The cause of this change may be related to the process of taking water around the river. During the process of water abstraction, the surface water-groundwater-groundwater hydraulic exchange, the $\mathrm{Ca}^{2+}$ in the river bed is taken out from the sediments, the proportion of $\mathrm{Ca}^{2+}$ ion is increased and the proportion of other ions is reduced. From the anionic triangles, it can be seen that the content of $\mathrm{HCO}_{3}{ }^{-}$is maintained at about $80 \%$ between Xianyang and Huaxian. All the water components are located in the central region, only Xianyang district is slightly biased towards $\mathrm{SO}_{4}^{2-}$, from $78 \%$ to $60 \%$, and river evaporation, surface water and groundwater exchange effects and other factors.

\section{Conclusions}

Because of the natural and artificial factors such as hydrogeology in the study area and access to water in the surrounding area, the supply, runoff and excretion of surface water and groundwater are determined. Based on the analysis of the hydrochemical characteristics of the subsurface zone in the Weihe River basin in Shaanxi, the following conclusions are drawn:

1) The $\mathrm{PH}$ value of the floodplain was in the range of 7.42 to 7.98 , the average $\mathrm{pH}$ value of river bank was 7.58, alkaline, and the TDS was in the range of 506.5 to 824 , with an average of $616.06 \mathrm{mg} \cdot \mathrm{L}^{-1}$, which was higher than that of the river water.

2) The river bank, beach area, river bed water are affected by carbonic acid.

3) The concentration of ions in the beach area is between the river bed and the river bank, which is close to the river bank concentration, indicating that the beach area receives both surface water and river water supply, and the groundwater recharge is obvious.

\section{Acknowledgements}

This research was financially supported by the research of National Natural Science Foundation of China (NSFC) No.51309107, 51409110. We also thankful to anonymous reviewer for his constructive comments in the manuscript review.

\section{References}

[1] Yuang, X.Z. and Luo, G.Y.A (2003) Brief Review for Ecological Studied on Hyporheiczone of Stream Ecosystem. Acta Ecologica Sinca, 23, 133-139.

[2] Feng, S.M., Song, J.X., Lai, W.L., Wang, Z. and Liang, W. (2013) An Overview of the Effects of Hyporheic Processes on the Streambed Hydraulic Conductivity in the Hyporheic Zone of a River. South to North Water Transfers and Water Science and Technoligy, 11, 123-125.

[3] Lai, K.R., Jiang, Z.J., Liu, X.H. and Zhou, W.B. (2011) Hydrochemical Properties of Shallow Groundwater along the Weihe River in Huaxian Country and Huaxiancity, Shannxi Province. Arid Zone Research, 28, 427-431.

[4] Zhang, G.X., Deng, W., He, Y., et al. (2006) Hydrochemical Characteristics and Evolution Las of Groundwater in Songnen Plain, Northeast China. Advances in Water Science, 17, 20-28. 
[5] Dou, Y., Hong, G.C. and Qian, H. (2010) Hydro-Geochemical Evolution of Groundwater in Arid and Semi-Arid Area. Journal of Arid Land Resources and Environment, 24, 88-92.

Submit or recommend next manuscript to SCIRP and we will provide best service for you:

Accepting pre-submission inquiries through Email, Facebook, LinkedIn, Twitter, etc. A wide selection of journals (inclusive of 9 subjects, more than 200 journals)

Providing 24-hour high-quality service

User-friendly online submission system

Fair and swift peer-review system

Efficient typesetting and proofreading procedure

Display of the result of downloads and visits, as well as the number of cited articles

Maximum dissemination of your research work

Submit your manuscript at: http://papersubmission.scirp.org/

Or contact gep@scirp.org 